\title{
Effect of early maternal newborn skin to skin contact in labour room on third stage of labour and success at breastfeeding
}

\author{
Purvi M. Parikh, Saumya P. Agrawal*, Rupa C. Vyas, Sapana R. Shah, Khushi P. Joshi
}

Department of Obstetrics and Gynecology, Smt NHL MMC, Ahmedabad, Gujarat, India

Received: 26 September 2018

Accepted: 22 October 2018

\section{*Correspondence:}

Dr. Saumya P. Agrawal,

E-mail: saumyaagrawal31192@gmail.com

Copyright: () the author(s), publisher and licensee Medip Academy. This is an open-access article distributed under the terms of the Creative Commons Attribution Non-Commercial License, which permits unrestricted non-commercial use, distribution, and reproduction in any medium, provided the original work is properly cited.

\begin{abstract}
Background: Immediate postpartum period and birth pose many challenges for the mother and the new-born. Initiation of early skin to skin contact in the labour room can be beneficial to both of them.

Methods: Randomized control trial conducted over a period of 7 months in a tertiary care centre enrolling 400 laboring women.200 in the control group were given routine care. In the 200women in the study group, the newborn was given immediate skin to skin contact by placing him/her on the mother's chest.

Results: Duration of third stage of labour was less than 10 minutes in $95 \%$ women of study group compared to 56\% women in the control group $(\mathrm{p}<0.01)$. Placenta was expulsed as a whole in $98 \%$ cases in the study group compared to $81 \%$ in the control group. Successful breastfeeding was observed in $88 \%$ women in study group compared to 54\%in the control group $(\mathrm{p}<0.01)$. Breastfeeding was initiated within 30 minutes of birth in $96 \%$ women in the study group compared to $41 \%$ in the control group.

Conclusions: Uterus could contract faster with the complete expulsion of placenta and shortening of the third stage of labour with early skin to skin contact. The newborn showed early initiation, success at breastfeeding and longer first breastfeeding with early skin to skin contact.
\end{abstract}

Keywords: Breastfeeding, Skin to skin contact, Third stage of labour

\section{INTRODUCTION}

India, though being a fast-developing country, still has very high maternal and neonatal mortality rates. It is the need of the hour to find out cost effective, easy and reliable ways to decrease these rates. In present study, we hence try to prove the statistical significance of giving early skin to skin contact in labour room on third stage of labour and success at breastfeeding.

Skin to skin contact is defined as holding the newborn in a prone position between the mother's breasts against her bare chest. The baby is undressed except for a diaper. ${ }^{1}$ The mother and the baby are covered with a blanket. Tactile stimulation provided by the baby promotes increase in the four major hormonal release in the mother:

- Oxytocin (the hormone of love)

- Endorphins (hormone of pleasure)

- Adrenaline and nor adrenaline (hormones of excitement)

- $\quad$ Prolactin (the mothering hormone). ${ }^{2}$

Oxytocin helps strengthening the uterine contractions allowing the placenta to separate faster. ${ }^{3}$ Endorphins and adrenaline mitigate postpartum depression and stress and improve the mother's bonding with the baby increasing her ability to care for the newborn. Prolactin increases the milk production. Objectives of the study are to determine 
the effect of early maternal-new-born skin to skin contact on third stage of labour, effect on success at breastfeeding and to check the feasibility of this method in a busy labour room in a tertiary care hospital of India.

\section{METHODS}

A total of 400 labouring women were enrolled in this randomized controlled trial conducted at a tertiary care centre over a period of seven months from $1^{\text {st }}$ November 2017 to $1^{\text {st }}$ June 2018 .

\section{Inclusion criteria}

- Primigravida

- $\quad$ Singleton pregnancy

- Full term (38-42weeks gestation)

- Cephalic presentation

- No complications (PIH, GDM, cardiac disease, etc)

- Vaginal delivery

- Age group 18-35years

- Willingness to join study

- Did not receive any pharmacological pain relief substance.

\section{Exclusion criteria}

- Mothers with severely retracted nipples

- Passage of meconium during labour

- Birth weight $<2500$ grams

- Floppiness or birth trauma

- Signs of respiratory distress at birth
- Major congenital anomalies were excluded from the study.

After an informed consent, eligible women in their second stage of labour were randomly assigned to either of the two groups- study and control through pre-mixed sealed envelopes with allocation cards.

In the control group, routine care was given to the babies. Cord was clamped and cut immediately, and the baby was handed to relatives after drying, suctioning and weighing. Breastfeeding was initiated after episiotomy suturing was completed. In the study group, skin to skin contact was given to the baby immediately after birth and cord was clamped later.

Baby was kept for 2 hours while suctioning and drying of the baby and suturing of mother's episiotomy was done simultaneously. Socio-demographic data was collected using a preformed questionnaire. Contraction of uterus was assessed by manual palpation of the abdomen. Placenta was examined for its completeness by assessment of its cotyledons and membranes.

Blood loss in the third stage was measured by placing a drape under the women's buttocks during delivery. Success at breastfeeding was determined using infant breastfeeding assessment tool where success meant score $>10$. This tool uses readiness to feed, rooting, latching and sucking with a max score of 12 to assess breastfeeding. Data calculations were done using statistical package for social sciences (SPSS) version 16. $P$ value was set at 0.01 to define statistical significance.

Table 1: Infant breastfeeding assessment tool. ${ }^{4}$

\begin{tabular}{|c|c|c|c|c|}
\hline & 3 & 2 & 1 & 0 \\
\hline $\begin{array}{l}\text { In order to get } \\
\text { baby to feed }\end{array}$ & $\begin{array}{l}\text { Placed the baby on } \\
\text { the breast as no } \\
\text { effort was needed. }\end{array}$ & $\begin{array}{l}\text { Used mild stimulation such } \\
\text { as unbundling, patting or } \\
\text { burping. }\end{array}$ & $\begin{array}{l}\text { Unbundled baby, sat baby back } \\
\text { and forward, rubbed baby's } \\
\text { body or limbs vigorously at } \\
\text { beginning and during feeding. }\end{array}$ & $\begin{array}{l}\text { Could not be } \\
\text { aroused. }\end{array}$ \\
\hline Rooting & $\begin{array}{l}\text { Rooted effectively } \\
\text { at once. }\end{array}$ & $\begin{array}{l}\text { Needed coaxing, prompting } \\
\text { or encouragement. }\end{array}$ & $\begin{array}{l}\text { Rooted poorly even with } \\
\text { coaxing. }\end{array}$ & Did not root. \\
\hline $\begin{array}{l}\text { How long from } \\
\text { placing baby on } \\
\text { breast to latch } \\
\text { and suck? }\end{array}$ & 0-3 minutes & 3-10 minutes & Over 10 minutes & Did not feed. \\
\hline Sucking pattern & $\begin{array}{l}\text { Sucked well } \\
\text { throughout on one } \\
\text { or both breasts. }\end{array}$ & $\begin{array}{l}\text { Sucked on and off but } \\
\text { needed encouragement. }\end{array}$ & $\begin{array}{l}\text { Sucked poorly, weak sucking; } \\
\text { sucking efforts for short periods. }\end{array}$ & $\begin{array}{l}\text { Did not } \\
\text { suck. }\end{array}$ \\
\hline
\end{tabular}

\section{RESULTS}

When socio-demographic data was analysed, there was no difference observed between the study and control groups (Table 2). Majority of women, $68 \%$ in study and
$72 \%$ in control group belonged to age group $18-26$ years. $57 \%$ women in study and $60 \%$ women in control group belonged to literate class. Most of the women, $84 \%$ in study and $78 \%$ in control group were homemakers. Only $14 \%$ women in the study group and $18 \%$ women in the 
control group came from distant rural areas. 69\% women in study group and $74 \%$ women in control group belonged to a family with income $>15,000$ rupees per month. Assessment of mother during third stage of labour showed that skin to skin contact improved uterine contraction, placental expulsion and reduced the requirement of uterotonics $(\mathrm{p}<0.01)$ (Table 3). Uterus contracted well within 5 minutes of birth in $94 \%$ in study group compared to $72 \%$ in control group $(\mathrm{p}<0.01)$.

Table 2: Whether socio-demographic data can confound the effect of skin to skin contact.

\begin{tabular}{|c|c|c|c|c|c|}
\hline Socio-demographic data & Study group $(n=200)$ & Control group $(n=200)$ & Chi value & P value & Statistical significance \\
\hline & $\mathbf{N}(\%)$ & $\mathbf{N}(\%)$ & & & \\
\hline \multicolumn{6}{|l|}{ Age in years } \\
\hline $18-26$ & $136(68)$ & $144(72)$ & \multirow{2}{*}{0.380} & \multirow{2}{*}{$\begin{array}{l}0.537 \\
(p>0.01)\end{array}$} & \multirow{2}{*}{ No } \\
\hline $27-35$ & $64(32)$ & $56(28)$ & & & \\
\hline \multicolumn{6}{|l|}{ Education } \\
\hline Literate & $114(57)$ & $120(60)$ & \multirow{2}{*}{0.774} & \multirow{2}{*}{$\begin{array}{l}0.374 \\
(p>0.01)\end{array}$} & \multirow{2}{*}{ No } \\
\hline Illiterate & $86(43)$ & $80(40)$ & & & \\
\hline \multicolumn{6}{|l|}{ Occupation } \\
\hline Homemaker & $168(84)$ & $156(78)$ & \multirow{2}{*}{1.160} & \multirow{2}{*}{$\begin{array}{l}0.281 \\
(p>0.01)\end{array}$} & \multirow{2}{*}{ No } \\
\hline Working & $32(16)$ & $44(22)$ & & & \\
\hline \multicolumn{6}{|l|}{ Residence } \\
\hline Urban & $172(86)$ & $164(82)$ & \multirow{2}{*}{0.595} & \multirow{2}{*}{$\begin{array}{l}0.440 \\
(p>0.01)\end{array}$} & \multirow{2}{*}{ No } \\
\hline Rural & $28(14)$ & $56(18)$ & & & \\
\hline \multicolumn{6}{|c|}{ Family income per month in rupees } \\
\hline$<15,000$ & $138(69)$ & $148(74)$ & \multirow{2}{*}{0.610} & \multirow{2}{*}{$\begin{array}{l}0.434 \\
(p>0.01)\end{array}$} & \multirow{2}{*}{ No } \\
\hline$\geq 15,000$ & $62(31)$ & $52(26)$ & & & \\
\hline
\end{tabular}

Table 3: Whether skin to skin contact had any effect of the third stage of labour.

\begin{tabular}{|c|c|c|c|c|c|}
\hline $\begin{array}{l}\text { Assessment of mother } \\
\text { during third stage }\end{array}$ & Study group (n=200) & Control group $(\mathrm{n}=\mathbf{2 0 0})$ & Chi value & P value & Statistical significance \\
\hline & $\mathbf{N}(\%)$ & $\mathbf{N}(\%)$ & & & \\
\hline \multicolumn{6}{|c|}{ Uterus contracts within 5 minutes of birth } \\
\hline Yes & $188(94)$ & $144(72)$ & \multirow{2}{*}{29.400} & \multirow{2}{*}{$\begin{array}{l}0.000 \\
(p<0.01)\end{array}$} & \multirow{2}{*}{ Yes } \\
\hline No & $12(06)$ & $56(28)$ & & & \\
\hline \multicolumn{6}{|c|}{ Completeness of placenta } \\
\hline Yes & $196(98)$ & $162(81)$ & \multirow{2}{*}{11.050} & \multirow{2}{*}{$\begin{array}{l}0.000 \\
(p<0.01)\end{array}$} & \multirow{2}{*}{ Yes } \\
\hline No & $04(02)$ & $38(19)$ & & & \\
\hline \multicolumn{6}{|c|}{ Need for ergometrine/PGF2a } \\
\hline Yes & $12(06)$ & $84(42)$ & \multirow{2}{*}{32.550} & \multirow{2}{*}{$\begin{array}{l}0.000 \\
(p<0.01)\end{array}$} & \multirow{2}{*}{ Yes } \\
\hline No & $188(94)$ & $128(64)$ & & & \\
\hline \multicolumn{6}{|l|}{ Blood loss $\geq 500 \mathrm{ml}$} \\
\hline Yes & $06(03)$ & $64(32)$ & \multirow{2}{*}{29.120} & \multirow{2}{*}{$\begin{array}{l}0.000 \\
(p<0.01)\end{array}$} & \multirow{2}{*}{ Yes } \\
\hline No & $194(97)$ & $136(68)$ & & & \\
\hline \multicolumn{6}{|c|}{ Duration of third stage of labour $\leq 10$ minutes } \\
\hline Yes & $190(95)$ & $112(56)$ & \multirow[b]{2}{*}{39.030} & \multirow{2}{*}{$\begin{array}{l}0.000 \\
(p<0.01)\end{array}$} & \multirow[b]{2}{*}{ Yes } \\
\hline No & $10(05)$ & $88(44)$ & & & \\
\hline
\end{tabular}

Placenta was expulsed as a whole in $98 \%$ cases in study group compared to $81 \%$ in the control group. Ergometrine/PGF2a was given in only 12 women in the study group compared to 84 women in the control group. The blood loss in the third stage was more than $500 \mathrm{ml}$ in $3 \%$ of study group compared to $32 \%$ of control group $(p<0.01)$. Duration of third stage of labour was less than 10 minutes in $95 \%$ women of the study group compared to $56 \%$ women in the control group (Figure 1). The first breastfeeding of the baby was assessed and there were statistical differences seen between the study and control group at $\mathrm{p}<0.01$ in terms of new-born attachment, initiation and duration of first breastfeeding (Table 4). The new-born could attach to the nipple and end the breastfeeding on its own in $97 \%$ and $90 \%$ women in the study group respectively compared to $60 \%$ and $58 \%$ respectively in the control group. Successful breastfeeding was observed in $88 \%$ women in the study group compared to only $54 \%$ women in the control group (Figure 2). 


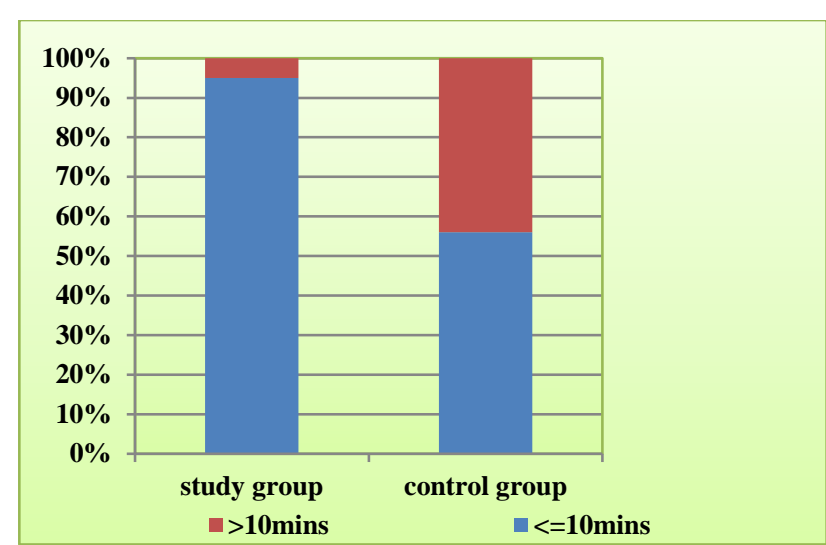

Figure 1: Comparison between study group and control group in terms of duration of third stage of labour.

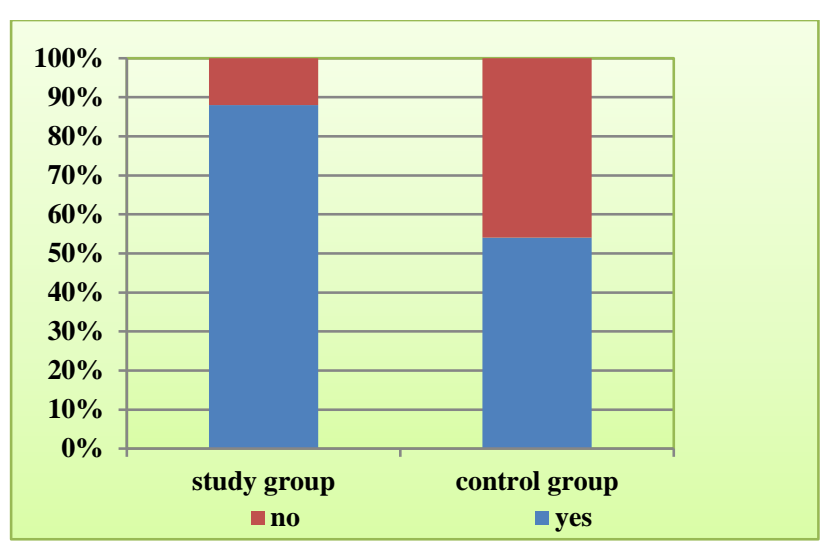

Figure 2: Comparison between study group and control group in terms of successful breastfeeding.

Table 3: Whether Skin to skin contact had any effect on the first breastfeeding of the baby.

\begin{tabular}{|c|c|c|c|c|c|}
\hline $\begin{array}{l}\text { Assessment of first } \\
\text { breastfeeding }\end{array}$ & $\begin{array}{l}\text { Study group } \\
(n=200)\end{array}$ & $\begin{array}{l}\text { Control group } \\
(n=200)\end{array}$ & Chi value & P value & $\begin{array}{l}\text { Statistical } \\
\text { significance }\end{array}$ \\
\hline & $\mathbf{N}(\%)$ & $\mathbf{N}(\%)$ & & & \\
\hline \multicolumn{6}{|c|}{ Newborn attach to nipple by himself/herself } \\
\hline Yes & $194(97)$ & $120(60)$ & \multirow{2}{*}{37.760} & \multirow{2}{*}{$0.000(\mathrm{p}<0.01)$} & \multirow{2}{*}{ Yes } \\
\hline No & $06(03)$ & $80(40)$ & & & \\
\hline \multicolumn{6}{|c|}{ Newborn end the breastfeeding by himself/herself } \\
\hline Yes & $180(90)$ & $116(58)$ & \multirow{2}{*}{26.610} & \multirow{2}{*}{$0.000(\mathrm{p}<0.01)$} & \multirow{2}{*}{ Yes } \\
\hline No & $20(10)$ & $84(42)$ & & & \\
\hline \multicolumn{6}{|c|}{ Successful breastfeeding (score $\geq 10$ ) } \\
\hline Yes & $176(88)$ & $108(54)$ & \multirow{2}{*}{37.550} & \multirow{2}{*}{$0.000(\mathrm{p}<0.01)$} & \multirow{2}{*}{ Yes } \\
\hline No & $24(12)$ & $92(46)$ & & & \\
\hline \multicolumn{6}{|c|}{ Time between delivery and initiation of breastfeeding } \\
\hline$\leq 30 \mathrm{mins}$ & $192(96)$ & $82(41)$ & \multirow{2}{*}{73.300} & \multirow{2}{*}{$0.000(\mathrm{p}<0.01)$} & \multirow{2}{*}{ Yes } \\
\hline$>30 \mathrm{mins}$ & $08(04)$ & $118(59)$ & & & \\
\hline \multicolumn{6}{|c|}{ Duration of first breastfeeding } \\
\hline$\geq 15 \mathrm{mins}$ & $190(95)$ & $114(57)$ & \multirow{2}{*}{79.160} & \multirow{2}{*}{$0.000(\mathrm{p}<0.01)$} & \multirow{2}{*}{ Yes } \\
\hline$<15$ mins & $10(05)$ & $86(43)$ & & & \\
\hline
\end{tabular}

Breastfeeding was initiated within 30minutes in $96 \%$ of study group compared to $41 \%$ of control group. The duration of breastfeeding was more than 15 minutes in $95 \%$ of study group compared to $57 \%$ of control group $(\mathrm{p}<0.01)$.

\section{DISCUSSION}

The present study shows statistically significant role of skin to skin contact on the time taken for the uterus to contract, time taken for expulsion of placenta, need for additional uterotonics and the amount of blood loss. This has been attributed to the action of oxytocin and of newborn's knees and legs pressing into the mother's abdomen giving it a massage. Similar findings were reported by a study carried out in Damanhur, Egypt which took into account the position of uterus between umbilicus and pubic bone and found it to be lower in the study group. ${ }^{5}$

They also showed that maternal satisfaction with care received was higher in the study group (98\%)compared to $66 \%$ in the control group, similar to the result of the study by Srivastava et al in Haryana, India. ${ }^{6}$ The study carried out in Baghdad, Iraq by Mejbel and Ali showed skin to skin contact decreased the duration of third stage while Joshi trial showed improved outcome in terms of height and hardness of uterus and pain experience by the mother. ${ }^{7,8}$ The study by Gabriel et al showed time to expel placenta was shorter after giving skin to skin contact while a study by Dordevic I showed it decreased the risk of postpartum haemorrhage. ${ }^{9,10}$ The present study also shows that skin to skin contact could lead to statistically significant early attachment of newborn to 
the nipple and early, successful and longer first breastfeeding. As stated in a study by Srivastava et al, the new-born is very much alert as a response to the surge in the catecholamine level and activation of locus ceruleus secondary to intermittent hypoxia during labour. ${ }^{6}$ His/her olfactory bulbs become supersensitive to odor cues from mother's nipples. The study proved that early skin to skin contact improved baby's suckling competence. The study by Redshaw et al stated that women who held their babies within 5 minutes of birth were more likely to initiate breastfeeding. ${ }^{11}$ The American college of nurse-midwives stated that with skin to skin contact, the baby will smell and find the nipple so that breastfeeding is initiated more rapidly. ${ }^{12}$ The study by Svensson et al in Stockholm, Sweden concluded that skin to skin contact shortens the time it takes to resolve severe latch on problems in the infants who started to latch. ${ }^{13}$ Similarly Mahmood et al (2011)14 and study by Khadivzadeh and Karimi in Iran stated that time to initiate first feed in study group was shorter than the control group. ${ }^{14,15}$ The Moore trial showed skin to skin contact enhanced the sucking competency $(\mathrm{p}<0.02)$ and achieved breastfeeding sooner $(p<0.04) .{ }^{16}$ However, the Carfoot et al trial had showed no difference in the success rate for the first feed and 4 months thereafter. This could be due to the difference in the scoring used to evaluate breastfeeding. ${ }^{17}$

\section{CONCLUSION}

Skin to skin contact led to faster contraction of uterus, complete expulsion of placenta, lesser need for uterotonics, lesser blood loss, shorter third stage of labour. It also led to new-born attaching to the nipple by himself, ending breastfeeding by himself, successful breastfeeding, faster initiation of breastfeeding, longer duration of first breastfeeding.

\section{Recommendations}

Skin to skin contact, being a fairly easy technique to perform, without having any extra need in terms of financial or manpower resources, should be performed routinely in a country like India at all places including the PHCs, CHCs as well as the tertiary care Centres. It can have a drastic positive effect on the NRHM data of India.

\section{Funding: No funding sources}

Conflict of interest: None declared

Ethical approval: Not Required

\section{REFERENCES}

1. Venancio S, Almeida H. Kangaroo Mother Care: scientific evidences and impact on breastfeeding. Journal de Pediatrica. 2004;80(5):S173-8.

2. Phillips R. The Sacred Hour: Uninterrupted Skin-toSkin Contact Immediately After Birth. Newborn and Infant Nurs Rev. 2013;13(2):67-72.
3. Kiss A, Mikkelsen J. Oxytocin - anatomy and functional assignments: A mini review. Endocr Regul. 2005;39(3):97-105.

4. Matthews MK. Developing an instrument to assess infant breastfeeding behavior in the early neonatal period. Midwife. 1988;4(4):154-65

5. Essa RM, Ismail NI. Effect of early maternal/newborn skin-to-skin contact after birth on the duration of third stage of labor and initiation of breastfeeding. J Nurs Edu Prac. 2015;5(4):98.

6. Srivastava S, Gupta A, Bhatnagar A, Dutta S. Effect of very early skin to skin contact on success at breastfeeding and preventing early hypothermia in neonates. Indian J Pub Health. 2014;58(1):22.

7. Mejbel M, Ali R. Effectiveness of Skin- to Skin Contact on duration of third stage of labour in Baghdad Teaching Hospital: Comparative Study. Kufa J Nurs Sci. 2012;2(3):1-13.

8. Joshi S. The effect of birth kangaroo care on maternal and neonatal outcome: A randomized, controlled trial. Sinhgad e J Nurs. 2012; 2(2):13- 7.

9. Marín Gabriel MA, Llana Martín I, López Escobar A, Fernández Villalba E, Romero Blanco I, Touza Pol P. Randomized controlled trial of early skin-to-skin contact: effects on the mother and the newborn. Acta Pædiatrica. 2010; 99(11): 1630-4.

10. Dordevic G, Jovanovic B, Dordevic M. An early contact with the baby - benefit for the mother. Medicina Preglio. 2008;61(11-12):576-9.

11. Redshaw M, Hennegan J, Kruske S. Holding the baby: Early mother-infant contact after childbirth and outcomes. Midwifery. 2014; 30(5):e177-87.

12. American College of Nurse-Midwives. Promoting Skinto-Skin Contact. J Midwife Women's Health. 2013;58(3):359-60.

13. Svensson KE, Velandia MI, Matthiesen AS, WellesNyström BL, Widström AM. Effects of mother infant skin-to-skin contact on severe latch-on problems in older infants: a randomized trial. Int Breastfeed J. 2013; 8(1): $1-13$.

14. Mahmood I, Jamal M, Khan N. Effect of mother-infant early skin-to-skin contact on breastfeeding status: a randomized controlled trial. Journal of the College Physician Surg-Pakistan: JCPSP. 2011;21(10):601-5.

15. Khadivzadeh T, Karimi A. The effects of post-birth mother-infant skin to skin contact on first breastfeeding. IJNMR. 2009;14(3):111-116.

16. Moore E, Anderson G. Randomized controlled trial of very early mother-infant skin-to-skin contact and breastfeeding status. J Midwifery Women's Health. 2007;52(2):116-25.

17. Carfoot S, Williamson P, Dickson R. A randomized controlled trial in the north of England examining the effects of skin-to-skin care on breast feeding. Midwifery. 2005;21(1):71-9.

Cite this article as: Parikh PM, Agrawal SP, Vyas RC, Shah SR, Joshi KP. Effect of early maternal newborn skin to skin contact in labour room on third stage of labour and success at breastfeeding. Int $\mathbf{J}$ Reprod Contracept Obstet Gynecol 2018;7:5011-5. 